\title{
APPLYING NORMATIVE THEORIES IN EU COMPETITION LAW: EXPLORING ARTICLE 102 TFEU
}

\author{
Stavros S. Makris*
}

\begin{abstract}
The present study involves an analysis of the two main normative approaches and intellectual traditions in competition law: the consequentialist and the deontological. The aim is to evaluate their merit in the application of positive law. Especially, this paper examines whether the traditional approaches offer a full account of the underpinning rationale of Article 102 TFEU and whether CJEU jurisprudence reflects a single intellectual tradition. Furthermore, three main legal tests are brought under scrutiny. These legal tests are invoked by the CJEU, in order to determine whether an infringement of Article 102 has occurred. The tests are associated with the abovementioned normative approaches. The scrutiny of the tests seeks to demonstrate the advantages and disadvantages of each normative approach in specific settings. The argument presented by the current analysis is that the two main normative approaches attempt to be holistic and reduce competition law to a single objective or goal. This produces serious shortcomings. Thus, it is preferable to adopt a value pluralistic normative theory aiming at creating a framework, which accommodates both consequentialist and deontological reasoning, when it is objectively justified. In terms of methodology, the argument is unravelled in a top-down method: first, it is presented on an abstract, theoretical level (Part C) and second, the rationale and application of Article 102 are examined so as to assess the general assumptions made in the first part (Parts D and E).
\end{abstract}

\section{A. INTRODUCTION}

Over the years, the EU authorities and courts have pursued various objectives within the framework of European Union competition law (EUCL). Freedom to compete, protection of market structure, protection of consumers, economic efficiency and market integration are only a few among the numerous goals recognised in positive law. ${ }^{1}$ The potential conflict between the goals of EUCL has often triggered various "hard cases" in the jurisprudence of the Court of Justice of the European Union (CJEU). In the absence of a coherent method for judicial decision-making, the plethora of objectives resulted in inconsistency and contradiction in CJEU jurisprudence, causing an adjudication problem. ${ }^{3}$ Several normative

\footnotetext{
${ }^{*}$ LL.B. (UoA), LL.M. (UCL). The author would like to thank Dr Ioannis Lianos for his guidance, continuous support and insightful comments on the subject. The author's thanks also go to Stavros Pantazopoulos and Michail Risvas for their helpful comments and suggestions. The usual disclaimer applies.

${ }^{1}$ Article 2, 3 and Protocol 27 of the Treaty on the European Union [2008] OJ C115/1; Ioannis Lianos, 'Competition law in the European Union after the Treaty of Lisbon' in Diamond Ashiagbor, Nicola Countouris, Ioannis Lianos (eds), The European Union after the Treaty of Lisbon (CUP 2012). Roger Van den Bergh and Peter Camesasca, European Competition Law and Economics: A Comparative Perspective (2nd edn, Sweet \& Maxwell 2006) 16-53.

${ }^{2}$ HLA Hart, The Concept of Law (Clarendon Press 1961) 124-154.

${ }^{3}$ Richard Whish and David Bailey, Competition Law (7th edn, OUP 2012) 19-20.
} 
theories have addressed the question of the goals of EUCL attempting to facilitate the resolution of this problem. The aim of this paper is to critically evaluate how normative theories of EUCL handle this adjudication problem. ${ }^{4}$

Normative theories are important in the discipline of competition law (CompL). They purport to understand the multifaceted phenomenon of competition, influence competition policy and suggest a method for decision-making. ${ }^{5}$ In addition, the normative foundations of EUCL affect the judicial decision-making, while, in a dialectical scheme, the Courts' jurisprudence influences the way the goals of EUCL are conceptualised. ${ }^{6}$

The plethora of goals can be summarised into two main normative accounts of EUCL. Hence, this paper follows a general jurisprudential taxonomy, which distinguishes between two main intellectual traditions: the consequentialist and the deontological. ${ }^{7}$ The first contends that competition is a mere instrument for maximising welfare. ${ }^{8}$ Thus, promoting economic efficiency should be the primary consideration and the telos of EUCL. ${ }^{9}$ The latter tradition argues that competition, which incorporates and reflects the idea of freedom, is a value per se. ${ }^{10}$ Therefore, safeguarding the competitive process and protecting the structure of the market must be an all-embracing objective. Both approaches employ a holistic perspective so as to reduce EUCL to a single ultimate goal.

However, it is submitted that neither is capable of releasing all existing internal tensions within EUCL, since both suffer from fundamental incompleteness. ${ }^{11}$ That being the case, value pluralism may offer a more coherent perception of EUCL's conceptual foundations than the other two schools of thought. Value pluralism does not claim to be a complete normative theory. It is based on the premise that there is no need for a strict and

\footnotetext{
${ }^{4}$ On the distinction between a positive (what the law actually is) and a normative (what the law ought to be) conception of law see Joseph Raz, The Authority of Law (OUP 1979) 37-52.

${ }^{5}$ Laura Parret, 'The multiple personalities of EU competition law: time for a comprehensive debate on its objectives' in D Zimmer (ed), The Goals of Competition Law (Edward Elgar 2012).

${ }^{6}$ David Gerber, 'The Goals of European Competition Law: Some Distortions in the Literature - Comment on Parret' in D Zimmer (ed), The Goals of Competition Law (Edward Elgar 2012).

${ }^{7}$ Ioannis Lianos, 'Some Reflections on the Question of the Goals of EU Competition Law', (2013) 3 CLES, 1 13, 31-32. This taxonomy assists in classifying the various objectives and schools to two main intellectual traditions in which they are subsumed.

${ }^{8}$ Simon Bishop and Mike Walker, The Economics of EC Competition Law (3rd edn, Sweet \& Maxwell 2010) 29-32.

${ }^{9}$ Robert Bork, The Antitrust Paradox: A Policy at War with Itself (Basic Books 1978); Richard Posner, Antitrust Law (2nd edn, UCP 2001); Karel van Miert, 'European Competition Policy' (Management Policy Council, 6 May 1998) <http://ec.europa.eu/competition/speeches/text/sp1998_053_en.html> accessed 25 August 2013.

${ }^{10}$ David Gerber, Law and Competition in Twentieth Century Europe: Protecting Prometheus (Clarendon Press 1998).

${ }^{11}$ Oles Andriychuk, 'Dialectical antitrust: an alternative insight into the methodology of EC competition law analysis in a period of economic downturn' (2010) 31 (4) ECLR 155, 163.
} 
rigid hierarchical prioritisation among EUCL's objectives. ${ }^{12}$ Therefore, it seeks to provide a framework which accommodates all the objectives of EUCL and encompasses both consequentialist and deontological reasoning when it is objectively justified. In that respect, it aims at informing the legal hermeneutics of EUCL and facilitating the settlement of the adjudication problem.

To assess the merit of the above normative approaches in relation to the adjudication problem, a top-down method is adopted. ${ }^{13}$ This involves a type of deductive reasoning, which starts from general assumptions, and, subsequently, narrows down to specific settings. ${ }^{14}$ The specific observations are used to confirm or reject the theoretical assumptions.

In the first part, the two main normative approaches with regard to the conceptual foundations of EUCL are compared. In addition, the contours of the value pluralistic approach are drawn in general terms. The second part is devoted to the analysis of Article 102 TFEU (Article 102). Article 102 is used as a case study to evaluate the merit or demerit of the abovementioned normative approaches. The analytical exercise is twofold: first, it assesses whether the traditional approaches offer a full account of the underpinning rationale of Article 102; second, CJEU jurisprudence is scrutinised to determine whether a single objective motivates the Courts' judgments.

The third part delves into an investigation of the three main legal tests, which the CJEU has invoked, in order to determine whether an infringement of Article 102 has occurred. ${ }^{15}$ Each test is associated with a normative approach in CompL discourse. The asefficient-competitor test (AECT) ${ }^{16}$ and the consumer harm test $(\mathrm{CHT})^{17}$ are interrelated with the "effects-based approach" and incorporate consequentialist thinking. On the contrary, the test of intent (ToI) induces certain deontological thinking in the legal analysis of "abuse". ${ }^{18}$ Concluding that the so-called holistic approaches cannot fully guide the interpretation and the

\footnotetext{
12 Abayomi Al-Ameen, 'Antitrust pluralism and justice' in D Zimmer (ed), The Goals of Competition Law (Edward Elgar 2012) 265-274.

13 Richard Posner, 'Legal reasoning from the Top Down and from the Bottom Up: The Question of Unenumerated Constitutional Rights' (1992) UCLR 433; James Griffin, On Human Rights (OUP 2008) 29-30; Paul Tomassi, Logic (Routledge 1999) 7-9.

${ }^{14}$ Keith Mason, 'Do top-down and bottom-up reasoning ever meet' in E Bant and M Harding (eds), Exploring Private Law (CUP 2010) 38-40.

${ }^{15}$ For the distinction between objectives, rules and tests see Renato Nazzini, The foundations of European Union competition law: the objective and principles of Article 102 (OUP 2011) 107-108.

${ }^{16}$ Einer Elhauge, 'Defining Better Monopolisation Standards' (2003) 56 SLR 253.

${ }^{17}$ Robert O'Donoghue and Atilano Padilla, The Law and Economics of Article 82 EC (Hart Publishing 2006) 191-194.

18 Antonio Bavasso, 'The role of intent under Article 82 EC: from "flushing the turkeys" to spotting lionesses in Regent's Park’ (2005) 26 (11) ECLR 616-623.
} 
application of Article 102, the paper suggests that a first step towards a value pluralistic approach of EUCL should be made.

\section{B. NORMATIVE THEORIES IN EUCL}

EUCL should not merely be an empirically formed set of ad hoc rules aiming at settling individual cases but rather a coherent and principled field of law. In this part, the paper considers how the two main normative approaches of EUCL address this problem. After presenting their salient features, it highlights that their incompleteness stems from their struggle to be holistic. The third section presents certain arguments for endorsing value pluralism and offers a general outline of its potential contribution to judicial decision-making.

\section{The Consequentialist Approach}

The topos of the consequentialist approach is that a normative standard should be evaluated exclusively depending on its consequences. ${ }^{19}$ It follows that an institution is justified as long as it achieves the greatest net balance of satisfaction for all individuals under its scope ${ }^{20}$ In CompL discourse, consequentialist thinking implies that the value of competition derives from its welfare maximising properties. ${ }^{21}$ Competition, like every other economic institution, is protected because it increases the welfare of society. ${ }^{22}$ Thus, EUCL should be instrumentalised for enhancing total or consumer welfare without having value per se. ${ }^{23}$ This view has become the current orthodoxy, since an increasing number of economists, practitioners, scholars and authorities suggest that economic efficiency should be the ultimate goal of CompL. ${ }^{24}$

Total welfare is defined as the sum of producer and consumer surplus in a given industry. ${ }^{25}$ This standard is related to the obsolete model of perfect competition, which the neoclassical economics postulate. ${ }^{26}$ Being based on a purely theoretical and heavily

\footnotetext{
${ }^{19}$ Walter Sinnott-Armstrong, 'Consequentialism', The Stanford Encyclopedia of Philosophy (Winter edn, 2012) <http://plato.stanford.edu/archives/win2012/entries/consequentialism/> accessed 25 August 2013.

${ }^{20}$ Henry Sidgwick, The Methods of Ethics (Macmillan 1907) 120-144.

${ }^{21}$ O’Donoghue and Padilla (n 17) 4; Bishop and Walker (n 8) 29-32.

22 Massimo Motta, Competition Policy: Theory and Practice (CUP 2004) 17-22.

${ }^{23}$ Martyn Taylor, International Competition Law: a new dimension for the WTO? (CUP 2006) 8-12.

${ }^{24}$ Motta (n 22) 17-22; O’Donoghue and Padilla (n 17) 4; Bishop and Walker (n 8) 29-32.

${ }^{25}$ Kenneth Arrow, 'An Extension of the Basic Theorems of Classical Welfare Economics' (1951) Proceedings of the Second Berkeley Symposium on Mathematical Statistics and Probability 507.

${ }^{26}$ Richard Lipsey and Alec Chrystal, Economics (OUP 2011) 136-159.
} 
unattainable ideal, such a perception of welfare encounters reasonable criticism, notwithstanding that it may lead to welfare loss in the long term. ${ }^{27}$

Total welfare is commonly understood as an application of the Kaldor-Hicks criterion. ${ }^{28}$ According to that criterion, "if an economic change results in some persons being better off and some worse off, and the winners could compensate the losers in such a way that, on balance, everybody was better off, then social welfare is greater even if no actual compensation has been made." ${ }^{29}$ Defined as Kaldor-Hicks efficiency, total welfare ignores the demands of distributive justice and this may be particularly detrimental in the European Union context. ${ }^{30}$

To say that someone is "better off" or "worse off" indicates that their utility increases or decreases, where utility represents a person's preferences as revealed in their choices. ${ }^{31}$ Nevertheless, it is a shaky assumption to claim that choices reflect specific preferences. ${ }^{32}$ Moreover, preferences may be irrational or based on false belief, ${ }^{33}$ be context-dependent ${ }^{34}$ or distorted $^{35}$ and cannot be compared with each other in relation to their content. Furthermore, the satisfaction of preferences may not increase a person's welfare. ${ }^{36}$ Additionally, focusing on preferences delimits competition analysis to the participants of the relevant market. ${ }^{37}$ Besides, a person's wellbeing is not simply what makes their life go well, but also what makes them a good person. ${ }^{38}$ Thus, wellbeing includes a non-economic dimension.

\footnotetext{
${ }^{27}$ For a critique of perfect competition see Whish and Bailey (n 3) 7-9; A Buchanan, Ethics Efficiency and the Market (Rowman \& Allanheld 1985) 14. For a critique of the axioms of rationality see A Sen, Collective Choice and Social Welfare (North-Holland 1984) 33-41. For a critic of Pareto optimal see Gregory Goldman, 'Simulation and Interpersonal Utility' (1995) Ethics 109. For a critique to short-term welfare see Nazzini (n 15) 32-39.

${ }^{28}$ Anthony Kronman, 'Wealth Maximization as a Normative Principle' (1980) 9 JLS 227, 236; John Hicks, 'The Foundations of Welfare Economics' (1939) 49 (196) EJ 696-712; Nicholas Kaldor, 'Comparisons of Utility' (1939) 49 (145) EJ 549-552.

${ }^{29}$ David Winch, Analytical Welfare Economics (Penguin Harmondsworth 1971) 143.

${ }^{30}$ Lianos (n 7) 8-13.

${ }^{31}$ Robin Broadway and Neil Bruce, Welfare Economics (Blackwell 1984) 235-261.

${ }^{32}$ Daniel Hausman, Preference, Value, Choice and Welfare (CUP 2012) 25-31.

${ }^{33}$ Daniel Hausman and Michael McPherson, 'Taking Ethics Seriously: Economics and Contemporary Moral Philosophy' (1993) JEL 31.

${ }^{34}$ Virgil Storr, Understanding the Culture of Markets (Routledge 2013) 57-82.

${ }^{35}$ Matthew Adler and Eric Posner, New Foundations of Cost Benefit Analysis (Harvard University Press 2006) 33.

${ }^{36}$ Thomas Scanlon, 'The Moral Basis for Interpersonal Comparisons' in Jon Elster and John Roemrer (eds), Interpersonal Comparisons of Well-Being (CUP 1993) 38.

${ }^{37}$ Richard Lipsey and Kelvin Lancaster, 'The General Theory of Second Best' (1956) 24 (1) The Review of Economic Studies 11-32.

${ }^{38}$ Joseph Raz, Ethics in the Public Domain: Essays in Morality of Law and Politics (Clarendon Press 1994) 4459.
} 
Total welfare is construed, by some authors, in a broad sense as including not only economic welfare but also values such as justice, fairness and other public goods. ${ }^{39}$ However, if such a definition of welfare is adopted, the consequentialist approach will be transformed into value pluralism, as will be shown below. This also contradicts the main theme of the welfarist approaches, according to which even non-economic welfare goals can be described in wellbeing terms. ${ }^{40}$

The alternative to total welfare, as many commentators argue is that the objective of CompL should be to prohibit behaviour that reduces consumer welfare. ${ }^{41}$ The main objection this standard encounters is that there is no specific, substantive reason for evaluating the welfare of consumers as bearing greater weight than that of producers. Moreover, prioritising consumer welfare is not likely to foster an economic approach in CompL and provide us with easier tests regarding the application of economic analysis. ${ }^{42}$ In addition, the main argument in favour of the consumer welfare objective derives from its potentially redistributive effect. ${ }^{43}$ Nonetheless, competition law under such an objective is ill-suited to pursue the redistribution of income, since it would be more efficient to realise distributive justice through the tax and transfer system. ${ }^{44}$

Moreover, consumer welfare has been used to disguise different objectives and ulterior purposes, thus confusing the debate and creating the false impression of a consensus. ${ }^{45}$ Although it was proposed as an instrument to defend economic freedom leading to a "lightweight antitrust", it generated false convictions and unnecessary interventions. ${ }^{46}$ Consequently, total welfare should be deemed as a superior objective than consumer welfare, since it relies on formal equality of all economic agents and values all economic agents equally. ${ }^{47}$

\footnotetext{
${ }^{39}$ Michal Gal and Eran Fish, 'Antitrust pluralism and justice-comment on Al-Ameen' in D Zimmer (ed), The Goals of Competition Law (Edward Elgar 2012) 285.

${ }^{40}$ Lianos (n 7) 4.

41 John B Kirkwood and Robert H Lande, The Fundamental Goal of Antitrust: Protecting Consumers, Not Increasing Efficiency (2008) 84 Notre Dame L Rev 191; Christopher Townley, Article 81 and Public Policy (Hart Publishing 2009) 177-181.

${ }^{42}$ Nazzini (n 15) 40-45. For an opposing view, see Steven Salop, 'Question: What is the Real and Proper Antitrust Welfare Standard? Answer: The True Consumer Welfare Standard' (2010) 22 Loy Consumer L Review 336.

${ }^{43}$ Russell Pittman, 'Consumer Surplus as the Appropriate Standard for Antitrust Enforcement' (2007) 3(2) CPI 205, 207-215.

${ }^{44}$ Louis Kaplow, 'On the choice of welfare standards in Competition Law' in D Zimmer (ed), The Goals of Competition Law (Edward Elgar).

${ }^{45}$ Herbert Hovenkamp, The Antitrust Enterprise. Principle and Execution (Harvard University Press, 2005) 1156.

${ }^{46}$ Eleanor Fox, 'We Protect Competition, You Protect Competitors' (2003) 26 (2) World Competition 149.

${ }^{47}$ Nazzini (n 15) 49-50.
} 
A detailed analysis of the various differences between total and consumer welfare is beyond the scope of this study. What is essential this far is to have demonstrated that these concepts reflect consequentialist thinking in EUCL. At the heart of this approach lies the following thesis: the good is defined independently from the right, and the right is conceived as what maximises the good. ${ }^{48}$ The consequentialist reasoning will support a conduct that generates more good than bad, even if it infringes other values such as freedom. In other words, an undertaking's conduct can be deemed "pro-" or "anti-" competitive merely in relation to its impact on welfare. Simultaneously, a purported anti-competitive conduct may be objectively justified as long as efficiency gains arising from it outweigh its distortive impact on competition.

This approach enables EUCL to take into account, in the form of "consequences", all the relevant economic evidence for assessing an undertaking's conduct. ${ }^{49}$ Furthermore, it avoids formalistic judgments since the legality of a conduct can be decided on the basis of its effects. Moreover, it provides useful analytical tools to deal with the problem of "false positives" and "false negatives", ${ }^{50}$ Despite that, if competition is a mere instrument to achieve efficiency and industrial growth it can be circumscribed on the grounds of an external value. ${ }^{51}$ For instance, both intervention and non-intervention could be justified, amounting to a selective and arbitrary protection of competition. This may deprive EUCL of a principled approach and reduce it to economics. Hence, the consequentialist approach may undermine the very notion of competition. This may transform EUCL into a fragile legal framework totally dependent on empirical analysis. ${ }^{52}$

In addition, economic efficiency cannot accommodate all societal values, since it is "unable to comprehend all the dimensions of human motivation and choice". ${ }^{33}$ The attempt to reduce all significant societal values to rational calculable variables may lead to situations where these values are not attributed their due gravity. For example, every restriction or violation of freedom or fairness could be legitimised on the basis of welfare maximisation.

\footnotetext{
${ }^{48}$ William Frankena, Ethics (Englewood Cliffs 1963) 13.

${ }^{49}$ Ioannis Lianos and Christos Genakos, 'Econometric evidence in EU competition law: an empirical and theoretical analysis' (2012) 6 CLES Working Paper Series.

${ }^{50}$ A false positive occurs when an authority, adopting an over-inclusive test, incorrectly considers a procompetitive behaviour as abusive, leading to false convictions. A false negative emerges where, under an underinclusive test, an anti-competitive behaviour is not prohibited, amounting to false acquittals. See Whish (n 3) 193; Arndt Christiansen and Wolfgang Kerber 'Competition Policy with Optimally Differentiated Rules Instead of "per se" vs Rule of Reason' 20062 (2) JCLE 215.

${ }^{51}$ Oles Andriychuk, 'Thinking Inside the Box: Why Competition as a Process is a Sui Generis Right - a Methodological Observation' in David Zimmer (ed), The Goals of Competition Law (Edward Elgar 2012).

${ }^{52}$ Andriychuk (n 11) 157-163.

${ }^{53}$ Lianos (n 7) 13.
} 
Diminishing the role of freedom and fairness may turn competition into an unjust institution. Accordingly, consequentialist thinking cannot provide a complete normative justification of EUCL, since it does not take all societal values equally seriously. ${ }^{54}$ Nonetheless, total welfare should be a value in EUCL and a significant element of every competition analysis, yet it cannot be an all-encompassing objective.

\section{The Deontological Approach}

The foundation of the deontological approach is that competition constitutes an end in itself, separate from the outcomes, which may be produced for consumers, economic efficiency, market integration or industrial growth. The process itself contains a significant economic importance and cannot be abolished, even if it is not always the most effective mode to reach welfare maximisation. ${ }^{55}$ Consequently, the process of competition should be protected on its own right as a sui generis right. ${ }^{56}$

The Ordoliberal School holds a prominent role in the deontological tradition. For ordoliberals, freedom is the essence of competition; therefore, its protection should be the principal goal of EUCL. ${ }^{57}$ Freedom to compete in a market with undistorted competition is dialectically intertwined with political freedom, namely the capability to participate freely in a fair political game. ${ }^{58}$ Likewise, a democratic polity requires and presupposes a free and fair market. ${ }^{59}$ The ideal is a social market economy where the rule of law is respected and state intervention aims to protect freedom from being abusively exercised. ${ }^{60}$ From this perspective,

\footnotetext{
${ }^{54}$ This point may rise from the critique Rawls advances against teleological theories in John Rawls, A Theory of Justice (revised edn, Harvard University Press 1999) 19-24.

${ }^{55}$ Andriychuk (n 51) 95-99.

${ }^{56}$ Roger Zach and Adrian Künzler, 'Freedom to Compete or Consumer Welfare: The Goal of Competition Law according to Constitutional Law' in Roger Zach, Andreas Heinemann and Andreas Kellerhals (eds), The Development of Competition Law - Global Perspective (Edwar Elgar 2010) 76.

${ }^{57}$ David Gerber, 'Constitutionalizing the Economy: German Neo-liberalism, Competition Law and the "New" Europe' (1994) 42 AJCL 71-73.

${ }^{58}$ Oliver Budzinski, 'Monoculture versus Diversity In Competition Economics' (2008) 32 CJE 305.

${ }^{59}$ Viktor Vanberg, 'The Freiburg School: Walter Eucken and Ordoliberalism' (2011) 4 Freiburg Discussion Papers on Constitutional Economics

<http://www.eucken.de/fileadmin/bilder/Dokumente/Diskussionspapiere/04_11bw.pdf> accessed 25 August 2013.

${ }^{60}$ E-J Mestmaker, 'The development of German and European competition law with special reference to the EU Commission's Article 82 Guidance of 2008' in Lorenzo Federico Pace (ed), European Competition Law: The Impact of the Commission's Guidance on Article 102 (Edward Elgar 2011) 25, 41.
} 
EUCL should strive to realise a humane order for society. ${ }^{61}$ It should be one of the foundations upon which liberal democracy and the economic constitution are established. ${ }^{62}$

Consequently, CompL must impose constraints on the exercise of both state and private power as the political institutions restrain the accumulation of political power. ${ }^{63}$ To achieve this, it should be oriented towards the ideal of complete competition, namely, competition in which no firm has power to coerce other firms in the relevant market. ${ }^{64}$ Complete competition is articulated under an "as if" standard. According to this standard, where market power cannot be eliminated, the bearer of it "should act as if constrained by competition". ${ }^{65}$ In that context, companies should be able to compete with each other and pursue their commercial interests while a strong regulatory framework would limit the capacity of the powerful market players and restrict the state from intervening in a manner distortive of market structure. ${ }^{66}$

Being principles-based, the deontological approach addresses the question of whether an action is right or wrong. ${ }^{67}$ It contends that a conduct can be right regardless of its consequences. Its correctness stems from its compatibility with a rule. Therefore, the deontological approach is grounded on value judgements and induces moral reasoning and evaluations in the discipline of CompL. The main objection against the deontological approach is that, since it values the competitive process irrespective of its consequences to the social welfare, it ignores economic analysis thus resulting in inflexible dogmatism. ${ }^{68}$ Once a commercial practice is categorised as impeding competition, its distortive effect on the market will be implied, without any ad hoc analysis. ${ }^{69}$

\footnotetext{
${ }^{61}$ Frank Maier-Rigaux, 'On the normative foundations of competition law - efficiency, political freedom and the freedom to compete' in Daniel Zimmer (ed), The Goals of Competition Law (Edward Elgar 2012) 132, 139.

${ }^{62}$ Giuliano Amato, Antitrust and the Bounds of Power: Dilemma of Liberal Democracy in the History of the Market (Hart 1997) 36.

${ }^{63}$ Gerber (n 10).

${ }^{64}$ Gerber (n 57) 50-52; Walter Eucken 'The Competitive Order and Its Implementation' (C Ahlborn and C Crave trs) (2006) 2(2) CPI 219. It should be highlighted though that complete competition is a rather static view of competition and, contrary to its advocates, seems to be close to a perfect competition ideal. Under complete competition the price is to be fixed in such a way that offer and demand are in equilibrium and marginal costs are just covered.

${ }^{65}$ Gerber (n 10) 252.

${ }^{66}$ Eucken (n 64) 248.

${ }^{67}$ Larry Alexander and Michael Moore, 'Deontological Ethics', The Stanford Encyclopedia of Philosophy (Winter edn 2012), <http://plato.stanford.edu/archives/win2012/entries/ethics-deontological/> accessed 28 August 2013.

${ }^{68}$ Christian Ahlborn and Atilano Padilla, 'From Fairness to Welfare: Implications for the Assessment of Unilateral Conduct under EC Competition Law' in CD Ehlermann and Mel Marquis (eds), European Competition Law Annual 2007: A Reformed Approach to Article 83 EC (Hart Publishing 2008).

${ }^{69}$ Lianos (n 7) 25.
} 
It would appear that competition, as an economic phenomenon, could be better understood through the language of economics. ${ }^{70}$ Certainly, economic concepts, as soon as they enter into the province of law, become part of it. ${ }^{71}$ Nevertheless, it cannot be argued that any form of deontological thinking denies efficiency considerations based on sound economic tools. ${ }^{72}$ In addition, the deontological approach engages in a different form of practical reasoning in comparison to the consequentialist approach. These elements are necessary for the application of the law. ${ }^{73}$ For instance, practical reasoning may restore the necessary link between legal categorisations and effects. Moreover, it highlights the importance of value judgements in EUCL discourse, providing a comprehensive justification for judicial decisions. For these reasons, the Court has developed, in many cases, an institutional conception of freedom and a comprehensive notion of fairness.

Furthermore, the deontological approach promotes an essential component of legal thinking: categorical thinking. ${ }^{74}$ Categorisation may ensure legal certainty and reduce enforcement costs. It may also enable the interpreter of the law to distinguish which evidence is relevant in each case. For this purpose, categories should rely on empirical evidence and the moral and legal principles inherent in law. Undoubtedly, these categories should be subject to revision according to economic theory. ${ }^{75}$ On this account, completely diminishing the importance of the deontological approach might prove destructive for the application of EUCL. ${ }^{76}$

\section{Beyond the Holistic Approaches: Value Pluralism}

Since the two main normative theories are not prescriptive enough to provide adequate guidelines for decision-makers and interpreters, a paradigm shift is necessary. ${ }^{77}$ The starting position of value pluralism is that there is no need for a strict hierarchical prioritisation among EUCL's objectives. ${ }^{78}$ A paradigm that encloses both consequentialist and

\footnotetext{
${ }^{70}$ Ioannis Lianos, 'Lost In Translation? Towards a Theory of Economic Transplants' (2009) 62 Current Legal Problems 353.

${ }^{71}$ Raz (n 4) 163-209.

${ }^{72}$ Maier-Rigaux (n 61) 163.

${ }^{73}$ Neil MacCormick, Legal Reasoning and Legal Theory (Clarendon Press 1978) 19-53.

${ }^{74}$ Ioannis Lianos, 'Categorical Thinking in Competition Law and the 'Effects-based' Approach in Article 82 EC' in Ariel Ezrachi (ed), Article 82 EC-Reflections on its recent evolution (Hart 2009) 35-37.

75 ibid 36-49.

76 Andriychuk (n 51) 106.

77 Andrichuck (n 11) 163

78 Al-Ameen, (n 12) 267-270.
} 
deontological reasoning would be more appealing when objectively justified. ${ }^{79}$ Thereby, the CJEU would decide every case through tailoring general principles to the specific context. Not being confined to a single tradition of reasoning, the Courts would be able to avoid the shortcomings of each tradition.

Firstly, the historic, societal and conceptual contexts of EUCL imply the absence of a single, unifying policy. Competition authorities and the EU Courts have not adhered to a specific "pure" normative theory. CompL does not exist in a vacuum, but is dialectically interwoven with the values of the society to which it pertains. It should reflect and promote various values. ${ }^{80}$ Therefore, it would be misleading to claim that the holistic approaches are more feasible than a new, not yet fully articulated theoretical paradigm.

Taking into consideration that CompL accommodates various competing interests and values, it is permeated by "reasonable disagreement". Reasonable disagreement synopsises the fact that in a heterogeneous society, people genuinely disagree about fundamental values. ${ }^{81}$ Public institutions rely on an array of irreducible independent values. Therefore, a legal regime should be reasonably accommodating, since social life is too rich in complicated details to permit resort to monistic overarching values. This is the only way to deal with the fact of reasonable disagreement. The phenomenon of competition cannot be reduced to a sole value. In addition, the morality inherent in EUCL is not based on a unitary value. ${ }^{82}$ Hence, the EUCL should be pluralistic in nature and seek for an "overlapping consensus". 83

Moreover, value pluralism is compatible with the notion of workable competition. The latter is a pragmatic ideal, since it rejects the very notion of perfect competition. ${ }^{84}$ Workable competition can be determined by a wide range of criteria such as economies of scale, low barriers to entry, or no impairment of freedom of choice. Value pluralism can provide further criteria for achieving workable competition. In addition, it can be aligned to reality-based economics and embrace their realistic assumptions or empirically founded

\footnotetext{
${ }^{79}$ Maria Baghramian, 'On the Plurality of Conceptual Schemes' in Maria Baghramian and Attracta Ingram (eds) Pluralism (Routledge 2000) 44-59.

80 William Galston, 'The Idea of Political Pluralism' in $\mathrm{H}$ Richardson and M Williams (eds), Moral Universalism and Pluralism (New York University Press 2008).

${ }^{81}$ Charles Larmore, 'Pluralism and reasonable disagreement' (1994) 11 (1) SPP 61.

${ }^{82}$ Al-Ameen (n 12) 261-266.

83 John Rawls, Political Liberalism (Columbia University Press 1993) 133-171.

${ }^{84}$ John M Clark, 'Toward a Concept of Workable Competition' (1940) 30 (2) AER 241-56.
} 
knowledge. ${ }^{85}$ For instance, a pluralistic approach is not committed to the homo economicus model which lies at the heart of the welfarist approaches. ${ }^{86}$

For that purpose, value pluralism attempts to provide a framework for ascertaining and balancing between the different goals that competition law promotes. ${ }^{87}$ Notwithstanding that fact, such an approach encounters a serious objection. It may be regarded as arbitrary or too theoretical to be applied by the courts. The answer to that objection is twofold: First, the potential arbitrariness could be diminished by an objective list of values that should be promoted. ${ }^{88}$ This general guide of goals based on empirical evidence may assist the Court in reaching a context-specific and principled decision. Second, should the CJEU engage in practical reasoning and value-judgements, it will be able to gradually form a coherent adjudication method. In other words, it would be illusory to argue that a single-value framework makes value-judgements redundant. ${ }^{89}$

A further function of value pluralisms could be that of providing a normative standard for interpreting positive law. This may be illustrated by the case of legal tests. Legal tests are articulations of the rules that the Court has developed so as to apply the law. Particularly in EUCL, these tests attempt to extricate restrictions of competition from anti-competitive behaviour. First, a potential test would be endorsed only if proven compatible with the values of EUCL. ${ }^{90}$ Stated otherwise, under value pluralism, each test invoked in the Courts' jurisprudence should satisfy a minimum requirement comprising values such as economic freedom, fairness, total welfare and legal certainty inter alia. Second, provided that a test is prima facie attuned to EUCL, value pluralism may highlight its shortcomings by invoking different goals from the one that triggered it. For example, a test prima facie compatible with EUCL will be considered less appealing when it is demonstrated that it involves costs surpassing its benefits. ${ }^{91}$ Thereby, it will be complemented by other tests or totally abandoned.

\footnotetext{
${ }^{85}$ Adrian Künzler, 'Economic content of competition law: the point of regulating preferences' in Daniel Zimmer (ed), The Goals of Competition Law (Edward Elgar 2012).

${ }^{86}$ Richard Thaler and Cass Sunstein, Nudge, Improving Decision about Health, Wealth and Happiness (Yale University Press 2008) 6-72.

${ }^{87}$ Al-Ameen (n 12) 271-273.

88 Amartya Sen, Commodities and Capabilities (North-Holland 1985) 33-39.

${ }^{89}$ Künzler (n 85) 183.

${ }^{90}$ This function can be inspired by Dworkin's conception of "integrity in law". See Ronald Dworkin, Law's Empire (Harvard University Press 1986) 225-275.

${ }^{91}$ Isaac Ehrlich and Richard Posner, 'An Economic Analysis of Legal Rulemaking' (1974) 3 JLS 257.
} 


\section{FROM THEORY TO PRACTICE}

So far the two main accounts of EUCL's conceptual foundations have been presented, this paper arguing that their potential completeness disguises their shortcomings. This increases the appeal of a value pluralist perspective of EUCL. The first section of this part examines whether the holistic approaches offer a coherent account of the role Article 102 TFEU plays in EUCL. The second section scrutinises whether the CJEU endorses a single ultimate goal in relation to Article 102. A value pluralistic approach is supported by the conclusion that the Court endorses a plethora of goals concerning Article 102, as its reasoning often invokes deontological and consequentialist thinking.

\section{Re-thinking Article 102: Form v Effects}

Article 102 is the cornerstone of EUCL on abuse of market power. It stipulates that unilateral practices of dominant undertakings should be deemed abusive in case they constitute a restriction of competition. Early case law on Article 102 can be summarised through two principal discussions: first, the Court examined whether the undertaking in question was dominant; and second, it assessed its practice in terms of form irrespective of its economic effects. ${ }^{92}$ The threshold for dominance was set relatively low and its satisfaction implied a per se prohibition of certain behaviour. ${ }^{93}$ Under this formalistic approach, a dominant firm was condemned merely due to its superior efficiency and market position and regardless of the effects of its conduct. ${ }^{94}$ This approach was correctly criticised for protecting the competitors rather than the competitive process, while it ignored current economic thinking. ${ }^{95}$ Mistakenly though, the root of the form-based approach was associated with deontological thinking in general. ${ }^{96}$

The publication of the European Commission's Guidance on the Commission's Enforcement Priorities in Applying Article [102] EC Treaty to Abusive Exclusionary Conduct by Dominant Undertakings (Guidance) proclaimed a departure from the form-based

\footnotetext{
${ }^{92}$ Gunnar Niels, Helen Jenkins and James Kavanagh, Economics for competition lawyers (OUP 2011) 180.

${ }^{93}$ Case T-203/01 Michelin v Commission [2003] ECR II-4071, paras 56-65; Case T-155/06 Tomra Systems ASA and Others. v European Commission [2010] ECR II-000, paras 208-210; Case C-95/04 P British Airways plc v EC Commission [2007] ECR I-2331.

${ }^{94}$ The debate was agitated by the Microsoft case. See Case T-201/04 Microsoft Corpn v Commission [2007] ECR II-3601, para 846.

${ }^{95}$ Bork (n 9) 427.

${ }^{96}$ From a value pluralist perspective, the form-based approach should be condemned because it relied on the dominant position as a shortcut to infer anti-competitive effects and downgraded the values of efficiency and consumer welfare.
} 
approach. ${ }^{97}$ Contrary to the approach followed so far by the Court, the Guidance attempted to introduce an effects-based approach concerning the interpretation of Article 102. The main feature of this approach was that it did not rely on the nature of the dominant undertaking's conduct or on in abstracto evaluations. ${ }^{98}$ Aiming at providing a solid economic foundation to Article 102, it developed a twofold test: first, a dominant undertaking's conduct can be deemed abusive due to its actual effects; second, an infringement of Article 102 could be based on a theory of harm, namely on an assumption that certain factual findings may cause harm to the consumers. Moreover, the adoption of the principle of objective justification introduced a "dialectical debate", where the Commission bears the burden of proving a prima facie infringement of Article 102, and the defendant should produce evidence of efficiencies with a sufficient degree of probability. ${ }^{99}$

The Guidance quickly became a useful point of reference summarising previous jurisprudence in a coherent manner while it paved the way for more economic-based rules and legal tests. The Commission in many cases, although not formally obliged to do so, scrutinised the effects of the practice in question. ${ }^{100}$ Following the same line, but not without oscillations, the Court gradually endorsed this approach, requiring proof of anti-competitive effects when it examined an allegedly abusive practice. ${ }^{101}$

Nevertheless, the deontological approach was falsely associated with formalism and per se presumptions. ${ }^{102}$ The origins of this confusion may lie in the fact that Article 102 was deemed an "ordoliberal provision". ${ }^{103}$ Subsequently, the Ordoliberal School was criticised for protecting "the competitors and not competition" and for inducing per se presumptions in EUCL. ${ }^{104}$ However, ordoliberal thinking does not necessarily prohibit the accumulation of power per se. It can be construed merely as making a value judgement, according to which

\footnotetext{
${ }^{97}$ European Commission, 'Guidance on the Commission's Enforcement Priorities in Applying Article 82 EC Treaty to Abusive Exclusionary Conduct by Dominant Undertakings' (Communication) 2009 OJ C45/7.

< Article 82 EC became Article 102 TFEU after renumbering under the Lisbon Treaty.

${ }^{98}$ Lianos (n 74) 19-49.

${ }^{99}$ Ekaterina Rousseva, "The Concept of "Objective Justification" of an Abuse of a Dominant Position: Can it Help to Modernise the Analysis under Article 82?' (2006) 2(2) CLR17 27, 33-34; Renato Nazzini, 'The wood began to move: an essay on consumer welfare, evidence and burden of proof' (2006) 31(4) ELR 518, 536.

100 Wanadoo España v Telefónica (COMP/38.784) Commission Decision 4 July 2007; Intel (COMP/C-3 137.990) Commission Decision 13 May 2009.

${ }^{101}$ Case C-280/08 P Deutsche Telekom AG v Commission [2010] ECR I-09555; Case C-52/09 Konkurrensverket v TeliaSonera Sverige AB [2011] ECR I-00527.

102 Per se abuses and irrebuttable presumptions deriving from deontological tradition are associated with excessive formalism and may be tantamount to a denial of the right of defence. See Mark Brealey, 'The Burden of Proof Before the European Court' (1985) 10 ELR 250, 255.

103 The allegedly ordoliberal influence on the drafting of Article 102 is vividly challenged in Pinar Akman, 'Searching for the Long-Lost Soul of Article 82 EC' (2009) 292 OJLS 267.

${ }^{104}$ Ahlborn and Padilla (n 68).
} 
the EUCL should prevent economic freedom from destroying its own prerequisites. ${ }^{105}$ It follows that economic freedom has an institutional character and is closely related to the structure of the market. This salient insight remains a value in the EUCL framework. Thus, even if Article 102 was an "ordoliberal provision", it should not have been biased in favour of competitors and against efficient dominant undertakings. What is more, the deontological approach is not confined to ordoliberal thinking. It induces practical reasoning and a workable form of categorical thinking in the EUCL; it may allow per se presumptions yet it does not necessitate them. Hence, it should not be mistakenly equated with the sterile and inadequate form-based approach.

The modernisation of Article 102 was necessary at the time, since its implementation had been throwing sand in the wheels of the market. ${ }^{106}$ The effects-based approach moved the EUCL away from crude deontological thinking, but it did not introduce a pure consequentialist account of Article 102. Should a fully-fledged effects-based approach have been endorsed, a mere analysis of the effects of a business conduct would have been sufficient for finding an abuse. This would imply that efficiency is not just a value embedded in Article 102 but rather its ultimate goal. Therefore, every categorisation under Article 102 should have been rejected as formalistic. ${ }^{107}$

The current approach combines both consequentialist and deontological thinking. ${ }^{108}$ It allows for taking into consideration the empirical evidence, while it demands a detailed economic analysis of them. Forming more economic-based rules neither exiles certain deontological thinking from EUCL nor does it substitute the law with economic analysis. ${ }^{109}$ Simultaneously, categorisations are indispensable to handling the indeterminacy of a pure consequentialist approach. ${ }^{110}$ For instance, categorical thinking is necessary for articulating a theory of harm or conducting a counterfactual test. Hence, the effects-based approach on Article 102 is not based exclusively on consequentialist thinking.

In the search for the objective of Article 102, all normative approaches struggle to rejoin one main question: under what circumstances should an undertaking's freedom to trade be prohibited? In other words, under which conditions should an undertaking's free trade

\footnotetext{
105 Wernhard Möschel, 'Competition Policy from an Ordo Point of View' in Alan T Peacock and Hans Willgerodt (eds), German Neo-Liberals and the Social Market Economy (Macmillan 1989) 149.

106 Joaquin Almunia, 'Converging paths in unilateral conduct' (ICN Unilateral Conduct Workshop, Brussels, 3 December 2010) <http://europa.eu/rapid/press-release_SPEECH-10-722_en.htm?locale=en> accessed 29 August 2013; James Venit, 'Article 82: The Last frontier - Fighting Fire with Fire' (2005) 28 FILJ 1157.

107 Akman (n 103) 267.

108 Lianos (n 74) 45.

${ }^{109}$ John Vickers, 'Abuse of market power' (2005) 115 EJ 244.

${ }^{110}$ Lianos (n 74) 19-35.
} 
activity be proscribed by Article 102? Despite its importance, there is no single, formal European Union document or decision establishing a single objective for Article 102. ${ }^{111}$ The Guidance may have endorsed consumer welfare as the basis for its enforcement priorities, yet it accepts "the significance of ensuring the competitive process in the internal market". ${ }^{112}$ Moreover, consumer welfare is not the only value that the Court has called on and cannot be an ultimate objective due to its various implications. ${ }^{113}$

Unequivocally, EUCL should be utilised to enhance consumer welfare and increase efficiency. ${ }^{114}$ Nonetheless, the markets should be kept open and fair while promoting innovation. ${ }^{115}$ In that respect, Article 102 seeks to protect a multitude of values and objectives. Concisely, protecting the undistorted competitive process for the benefit of the consumers should be held as the underpinning rationale of Article 102. As a result, the limits imposed on the unilateral conduct of a dominant undertaking by Article 102 should aim to protect the market structure and the competition as a process, so as to avoid consumer harm. Therefore, the multitude of objectives which constitute the underpinning rationale of Article 102 lead to a pluralistic perspective. Contrary to the holistic approaches, this perspective recognises that the understanding and the coherent application of Article 102 requires a conceptual framework in which both consequentialist and deontological thinking coexist.

\section{Pluralism in CJEU Jurisprudence}

It has been illustrated that both the consequentialist and the deontological school of thought cannot wholly explain the current approach concerning the interpretation of Article 102. This section examines whether the CJEU favours the plurality of goals or if the Courts' decisionmaking can be reduced to a single and ultimate objective.

Beyond doubt, the notion of economic efficiency is central to the CJEU reasoning. Firstly, "dominance" is defined as "a position of economic strength which enables an undertaking to prevent effective competition". ${ }^{116}$ Furthermore, any reference to public interest induces a total welfare standard. Restrictions of competition may stem from abusive

\footnotetext{
111 O’Donoghue and Padilla (n 17) 4.

112 Guidance (n 97), para 6.

${ }^{113}$ Department of Justice, 'Competition and Monopoly: Single-firm Conduct Under Section 2 of the Sherman Act' (2008). This report was withdrawn in 2009, but the critique it contains remains valid on this issue.

${ }^{114}$ Neelie Kroes, 'Preliminary, 'Thoughts on Policy Review of Article 82' (Speech at the Fordham Corporate Law Institute, 2005) <http://europa.eu/rapid/press-release_SPEECH-05-537_en.htm> accessed 29 August 2013, 3 .

115 Almunia (n 106) 3.

${ }^{116}$ Case C-27/76 United Brands v Commission [1978] ECR I-207, para 65.
} 
practices which undermine the public interest and the wellbeing of the EU. ${ }^{117}$ Furthermore, the CJEU has highlighted that "efficiencies should be taken into consideration under the overall economic assessment of the conduct at hand". ${ }^{118}$ In other words, it has to be determined whether the allegedly anti-competitive effect arising from a dominant undertaking's practice can be "outweighed by its advantages in terms of efficiency". 119 Additional support to welfarist approaches is given by the Guidance, which adopts a consumer welfare standard and allows for allegedly anti-competitive conduct to be objectively justified. ${ }^{120}$ The Commission's "economic approach" may lean on a consequentialist standard such as "consumer welfare", but undoubtedly, courts and competition authorities are nowhere near adopting this standard as an ultimate objective.

Influenced by ordoliberal thinking, the EU Courts have proclaimed that the "special responsibility" of the dominant undertaking "does not allow its conduct to impair genuine undistorted competition". ${ }^{121}$ If anticompetitive effects were the rationale of the said special responsibility, all firms with market power would bear such a responsibility. ${ }^{122}$ Market access, equality of opportunity and protection of freedom to compete have also triggered the recognition of such a responsibility. In her Opinion in British Airways, AG Kokott contended that Article 102 "is not designed only or primarily to protect the immediate interests of individual competitors or consumers, but to protect the structure of the market and thus competition as such". 123

Furthermore, in many cases the Court associates individual wellbeing with the single market imperative, highlighting that Article 102 should seek to preserve undistorted competition in the market so as to increase social welfare. ${ }^{124}$ In GlaxoSmithKline, the Court utilised the notion of final consumers and consumer choice to restrict a dominant undertaking's freedom to compete and establish a link between restrictions of parallel trade

\footnotetext{
${ }^{117}$ Konkurrenverket v TeliaSonera Sverige AB (n 102), paras 21-24.

118 Case C-6/72 Europemballage Corp and Continental Can Co Inc v Commission [1973] ECR 215, para 25.

${ }^{119}$ British Airways plc (n 93), para 86.

${ }^{120}$ Guidance (n 97), paras 5, 28-31

${ }^{121}$ Guidance (n 97), paras 1-9; Case C-322/81 NV Nederlandsche Banden Industrie Michelin v Commission [1983] ECR I-3461, para 57; Microsoft v Commission (n 94), para 775; British Airways plc (n 94), Opinion of AG Kokott, para 23.

122 Lianos (n 74) 24.

${ }^{123}$ British Airways plc (n 93), para 68.

${ }^{124}$ TeliaSonera (n 101), paras 21-24; Case T-321/05 AstraZeneca AB and AstraZeneca plc $v$ European Commission [2010] ECR II-2805, para 804; Case T-168/01 GlaxoSmithKline Services Unlimited v Commission [2006] ECR 2969, para 118; Joined Cases T-213/01 and T-214/01 Österreichische Postsparkasse AG and Bank für Arbeit und Wirtschaft AG v Commission [2006] ECR II-1601, para 115.
} 
and anti-competitive effects. ${ }^{125}$ Therefore, it recognised that market integration and consumer sovereignty might impose certain limitations to economic freedom.

In addition, the principle of fairness has inspired many Court judgments. The CJEU has consistently held that "a system of undistorted competition can be guaranteed only if equality of opportunity is secured among the various economic operators". ${ }^{126}$ Additionally, equality of opportunity indicates that as-efficient rivals should be on equal footing in the relevant market. ${ }^{127}$ For instance, dominant undertakings should abstain from predation since it is deemed "unfair". ${ }^{128}$ By the same token, rebate schemes pursued by a dominant undertaking were found to be abusive when they proved to be unfair to the affected consumers. ${ }^{129}$

To conclude, the main question under Article 102 is how to distinguish between abusive behaviour and competition on merits. The European courts may have induced certain deontological thinking in the application of Article 102. Nevertheless, when this started to amount to formalism, an effects-based approach emerged, attempting to modernise our understanding of the relevant provision. ${ }^{130}$ This consequentialist interpretive attitude has not been boundless. Other goals, besides efficiency, have prescribed the limits of the effectsbased approach and have emphasised the necessity of categorical thinking. The Court has been interpreting EUCL under a framework of multiple objectives without relying solely on a single objective or school of thought. ${ }^{131}$ Such an approach indicates that EUCL adheres to goals pluralism and validates the main thesis of value pluralism.

\section{ARTICLE 102 UNDER THE MICROSCOPE: THE LEGAL TESTS}

In this part, three main tests regarding an infringement of Article 102 are brought under scrutiny. The AECT and the CHT stem from the consequentialist approach. ${ }^{132}$ The ToI is grounded on an effects-based test, yet transcending it as it engages in certain deontological

\footnotetext{
${ }^{125}$ Case C-468/06 to 478/06, Sot Lelos kai Sia v GlaxoSmith Kline [2008] ECR I-07139, para 67.

${ }^{126}$ Case C-18/88 GB-Inno-BM [1991] ECR I-5941, para 25; Case C-462/99 Connect Austria [2003] ECR I5197, para 83; Joined Cases C-327/03 and C-328/03 ISIS Multimedia Net and Firma O2 [2005] ECR I-8877, para 39; Case C-49/07 MOTOE [2008] ECR I-4863, para 51.

${ }^{127}$ Deutsche Telekom v Commission (n 101), para 233.

${ }^{128}$ British Airways (n 93), para 47.

${ }^{129}$ Michelin (n 93), para 97.

${ }^{130}$ Motta (n 22) 34-36.

${ }^{131}$ Lianos (n 7) 32, 37.

${ }^{132}$ Indicatively, the AECT is supported among others by Posner (n 9) 194-195; Elhauge (n 16) 253. The CHT is advocated by Herbert Hovenkamp, 'Exclusion and the Sherman Act' (2005) 72 UCLR 147; O'Donoghue and Padilla (n 17) 191-194; Steven Salop, 'Exclusionary Conduct, Effect on Consumers, and the Flawed Profit Sacrifice Standard' (2006) 73 ALJ 311.
} 
thinking. ${ }^{133}$ Should a single test be applicable to all conceivable abusive practices, it would be implied that there is indeed an ultimate objective of Article 102 from which the relevant test derives. ${ }^{134}$ Thereby, a pluralistic approach will have to be refuted. ${ }^{135}$

\section{The As-Efficient-Competitor Test (AECT)}

It is a generally accepted idea that by protecting less efficient competitors, there is an unavoidable risk of protecting competitors rather than competition itself. ${ }^{136}$ Seeking to avoid such an incident, the CJEU in a series of cases developed the as-efficient-competitor test (AECT). ${ }^{137}$ Its rationale is that the most efficient firm should be the competitive winner. ${ }^{138}$ Thus, harmful, anti-competitive exclusion should be distinguished from "exclusion" as a result of undistorted competition on the merits. ${ }^{139}$ For that purpose, the AECT examines whether a dominant undertaking's conduct constitutes an exclusionary practice by foreclosing from the relevant market an as-efficient rival. ${ }^{140}$ Consequently, practices such as tying, bundling or conditional rebates pursued by a dominant undertaking are deemed abusive only if they are capable of such a foreclosure effect.

In $A K Z O$, the Court held that prices above average variable cost (AVC) but below average total cost (ATC) are abusive if they form part of an exclusionary plan that intends to eliminate an equally efficient competitor. ${ }^{141}$ In Deutsche Telekom, the Court considered as abusive a dominant undertaking's pricing practice (margin squeeze). According to the Court's reasoning, these practices were capable of a foreclosure effect to the detriment of competition on the merits. ${ }^{142}$ In TeliaSonera, the AECT indicated the existence of margin

\footnotetext{
${ }^{133}$ A consequentialist variant of the ToI is favoured by Douglas Melamed, 'Exclusionary Conduct Under the Antitrust Laws: Balancing, Sacrifice, and Refusals to Deal' (2005) 20 BTLJ 1247; Gregory Werden, 'Identifying Exclusionary Conduct Under Section 2: The "No Economic Sense" Test' (2006) 73 ALJ 413. It is submitted that the "no economic sense" test, promoted by the last two authors, is merely a subset of the ToI.

${ }^{134}$ Many authors contend that there is a single test for the assessment of abusive conduct. Indicatively, the AECT is supported among others by Posner (n 9) 194-195; Elhauge (n 16) 253.

${ }^{135}$ A test-pluralism is recommended by Andrew Gavil, 'Exclusionary Distribution Strategies by Dominant Firms: Striking a Better Balance' (2004) 72 ALJ 3; Vickers (n 109) 244; Marina Lao, 'Defining Exclusionary Conduct Under Section 2: The Case for Non-Universal Standards' in BE Hawk (ed), International Antitrust Law \& Policy: Fordham Competition Law 2006 (Juris Publishing 2007) 433; Mark Popofsky, 'Defining Exclusionary Conduct: Section 2, the Rule of Reason, and the Unifying Principle Underlying Antitrust Rules' (2006) 73 ALJ 435, 443.

${ }^{136}$ O’Donoghue and Padilla (n 17) 389-393.

${ }^{137}$ Case C-209/10 Post Danmark A/S v Konkurrencerådet [2011] 4 CMLR 982; Case T-336/07 Telefónica SA and Telefónica de España SAU v Commission, judgment of 29 March 2012 (not yet reported) (appeal pending).

${ }^{138}$ Künzler (n 85) 182.

${ }^{139}$ Competition on the merits may lead to the exclusion of less efficient competitors. See Post Danmark A/S $v$ Konkurrencerådet (n 137), para 22.

${ }^{140}$ Posner (n 9) 194.

${ }^{141}$ Case C-62/86 Akzo Chemie BV v Commission [1991] ECR I-3359 paras 71-72.

${ }^{142}$ Deutsche Telekom AG (n 101), paras 177-183.
} 
squeeze. Should a dominant firm be unable to offer its retail services other than at a loss, it follows that competitors who are potentially excluded by the relevant practice should be deemed as-efficient. ${ }^{143}$

By applying the AECT the Court avoided a form-based approach and held that pricing practices, such as conditional rebates, price discrimination, predatory pricing and margin squeeze are not per se exclusionary. These practices should be regarded as abusive only when they are linked to certain anti-competitive effects. The latter are established by demonstrating that an equally efficient competitor is excluded from the market due to the relevant pricing strategy.

The AECT is consistent with the principle of economic freedom. Article 102 is not there to prevent an undertaking from becoming, on its own merits, dominant on the market. Freedom to compete should, by definition, amount to the exclusion from the market of the less efficient competitor. ${ }^{144}$ Whether inefficient companies can actually survive in competition with the efficient ones is a question to which the answer should only be revealed in the course of competition. Moreover, only conduct that constrains the freedom of action of other market actors, without being objectively justified or bringing efficiency gains, should be prohibited as abusive.

Furthermore, the AECT allows a dominant undertaking to benefit from its superior efficiency, while it remains neutral towards all undertakings, distinguishing them solely under the objective criterion of efficiency. Nonetheless, a question of fairness may arise. It can be argued that freedom of market access, which reflects equality of opportunity, should not be protected or prevented on the basis of current efficiency. ${ }^{145}$ It is possible for the dominant undertaking to exclude its competitors so as to repudiate them from achieving their minimum efficiency standards. ${ }^{146}$ For instance, the costs for a new entrant will most likely be higher than those of the dominant firm until economies of scale are fully achieved. Should the dominant firm in such a market pursue a potentially abusive practice, it may eliminate a new entrant's opportunity to achieve the minimum efficient scale. Thus, the competitor is prevented from becoming as efficient as the dominant firm by the conduct of the latter. Accordingly, on certain occasions the AECT does not fully realise the principle of fairness and should be complemented by other legal tests.

\footnotetext{
${ }^{143}$ TeliaSonera (n 101), para 43.

${ }^{144}$ Ekaterina Rousseva and Mel Marquis, 'Hell freezes over: A climate change for assessing exclusionary conduct under Article 102 TFEU' (2013) 4(1) JECLP 30, 42.

145 Künzler (n 85) 201-212

${ }^{146}$ Hovenkamp (n 132) 154-155.
} 
The AECT deals properly with the incentives problem by adopting the efficiency of the dominant firm as a benchmark. On the one hand, actual and potential competitors, knowing that they can succeed only by advancing superior efficiency than the dominant undertaking, will have a strong incentive to be more efficient than the dominant firm. On the other hand, the dominant firm retains the incentive to increase its efficiency since it is not deterred by an authority's intervention from acting in accordance with its commercial interests.

In addition, achieving adequate legal certainty is considered a significant advantage of the AECT. Dominant firms are able to predict the legality of their conduct, being required to know solely their own cost-structure so as to assess their performance ex ante. ${ }^{147}$ However, when applying for conditional and multi-product rebates the AECT insists on additional information regarding the structure of the market. ${ }^{148}$ Moreover, the AECT cannot readily be applied to non-price conduct such as tying and bundling, inasmuch as there is no certain way of determining what the counterfactual price would have been. ${ }^{149}$

As indicated above, the AECT is mainly justified economically on grounds of actual economic welfare. In principle, the short-term welfare effects of the test are deemed to be clear. It allows, for instance, a dominant undertaking to solely offer the rebates which the less-efficient competitor cannot offer. Thereby, the less-efficient competitors are excluded from the market and both total and consumer welfare increase.

Notwithstanding, in particular cases, excluding a less-efficient competitor may be incompatible with social welfare, raising the problem of false negatives. ${ }^{150}$ For instance, the entry of a less-efficient rival can improve total welfare in occasions where the gain in allocative efficiency outweighs the harm caused to productive efficiency. ${ }^{151}$ Hence, it should be accepted that the AECT cannot provide a unified theory of the assessment of different forms of abuse. ${ }^{152}$

In certain cases, non-intervention regarding the exclusion of a less-efficient competitor may allow the dominant firm to defend a market position from which a net long-

\footnotetext{
${ }_{147}$ Melamed (n 133) 375-388; Deutsche Telekom AG (n 128) [192].

148 O’Donoghue and Padilla (n 17) 389-393.

${ }^{149}$ Martin Mandorff and Johan Sahl, 'The Role of the 'Equally Efficient Competitor' in the Assessment of Abuse of Dominance', Working Paper (2013) 1

<http://www.kkv.se/upload/Filer/Trycksaker/Rapporter/WorkingPaper/working_paper_2013-1.pdf> accessed 25 August 2013.

150 Vickers (n 109) 259-250.

151 ibid 244-256.

152 Mandorff and Sahl (n 149) 18.
} 
term welfare loss may follow. ${ }^{153}$ Over time, inefficient companies can turn into as-efficient companies since competition is an open-ended process. This problem can be solved if the AECT is supplemented by another test that appraises whether the excluded competitor provided an "effective competitive constraint" on the dominant firm. ${ }^{154}$

To conclude, the AECT strives to deal with a fundamental contradiction that lies beneath all law in relation to abuse of market power. In other words, it attempts to safeguard rivalry by curtailing it. As demonstrated above, this test can be under-inclusive and overinclusive, allowing certain false positives and false negatives. As a result, it does not always contribute to welfare maximisation. Furthermore, in some instances it is not fully satisfactory from a fairness perspective, while at the same time, the legal certainty it provides can be called into question. Whilst it is inappropriate as the sole and single test for exclusionary abuses, it remains a useful test.

\section{The Consumer Harm Test (CHT)}

The CHT is an effects-balancing test which focuses on the consequences of the conduct on total or consumer welfare. Its salient assumption is that consumer harm can be caused by maintaining or strengthening market power and subsequently by raising prices or restricting output. ${ }^{155}$ Under this standard, an exclusionary conduct violates EUCL in case it diminishes competition without fully offsetting these potential adverse effects. ${ }^{156}$ Accordingly, an exclusionary conduct should be deemed abusive as long as it does not fully benefit consumers. ${ }^{157}$ Hence, the CHT makes illegal any conduct by which a dominant undertaking strengthens its market position causing net harm to consumers.

The principle of fairness may endorse the CHT. Such a test allows for an objective consideration of the negative and positive effects of certain conduct in a neutral and principled way. Furthermore, limiting a dominant undertaking's freedom to compete on grounds of consumer harm cannot be held as arbitrary. Economic freedom does not include practices that harm consumers, insofar as such practices constitute abusive exercise of the relevant freedom. Hence, economic freedom and fairness do not provide any reasons for abandoning the relevant legal test.

\footnotetext{
153 Nazzini (n 15) 74-76.

${ }^{154}$ Bavasso (n 18) 616, 621.

155 Salop (n 132) 329-330.

156 ibid 330.

157 Phillip Areeda and Herber Hovenkamp, Antitrust Law: An Analysis of Antitrust Principles and Their Application (Aspen 2001) 72.
} 
At first glance, the CHT seems to be a clear test providing legal certainty. It claims that a conduct is anti-competitive only if it harms consumers. ${ }^{158}$ However, it may impose a significant administrative challenge to the courts for it requires conducting an open-ended scrutiny of the effects of the practice in question. ${ }^{159}$ This entails a comparison between a current and a hypothetical situation. Moreover, economists' ability to accurately measure the net consumer-welfare effects of particular conduct and judges' ability to evaluate this evidence are confined by certain limitations. ${ }^{160}$ Since dynamic effects are often difficult to assess, the CHT may lead courts to focus too much on static, short-run consumer effects. Even if the relative short-term economic effects are evaluated, there could not be an accurate economic assessment of the long-term effects on innovation and risk-taking. ${ }^{161}$ At the same time, it would be difficult for firms to predict whether their conduct violated Article 102.

Be that as it may, a total welfare standard dictates adopting CHT. In a wellfunctioning market, it can be expected that firms will pass on their lower costs to consumers through lower prices, better services or investment in research and development. Nonetheless, the administrative difficulties of a CHT may reduce a dominant firm's incentives to engage in pro-competitive practices. It should be highlighted that the standard of proof for establishing consumer harm is relatively low; it is not required to prove the existence of an actual or a direct consumer detriment. ${ }^{162}$ Consequently, it may lead dominant firms to abandon conduct that would generate efficiencies and be beneficial to total welfare in the long run. ${ }^{163}$ Therefore, the over-deterrence effect of the test subjects it to false positives. Nevertheless, under the CHT a dominant firm may attempt to objectively justify its conduct by suggesting that it generates efficiencies which outweigh the harm to consumers. ${ }^{164}$ Conversely, it is rather difficult for the defendant to establish objective justifications and thereby outweigh the anticompetitive effects. ${ }^{165}$

On the other hand, reinforcing the standard of proof in the application of the CHT may give rise to systematic false acquittals and under-deterrence. ${ }^{166}$ That being the case, it will become very difficult for the claimant to establish consumer harm and, subsequently, the

\footnotetext{
${ }^{158}$ In EUCL the concept of 'consumers' is tantamount to 'customers', since it encompasses all direct or indirect users of the products affected by the conduct: see Guidance (n 97), para 19.

${ }^{159}$ Melamed (n 133) 379-388.

${ }^{160}$ Werden (n 133) 431-32; Elhauge (n 16) 317.

${ }^{161}$ Popofsky (n 135) 431-445.

${ }^{162}$ British Airways plc (n 93), para 106.

${ }^{163}$ Melamed (n 133) 387.

${ }^{164}$ Damien Neven and Lars Röller, 'Consumer Surplus vs Welfare Standard in a Political Economy Model of Merger Control' (2005) 23 IJIO 829.

165 Giorgio Monti, EC Competition Law, (1st edn, CUP 2007) 203.

166 Nazzini (n 15) 92-100.
} 
test will ex ante incentivise dominant firms to engage in anti-competitive conduct. To avoid false negatives an enhanced dominance threshold should be required. ${ }^{167}$ Adopting such a standard implies that exploitative abuses are be committed only by a monopolist or quasimonopolist. ${ }^{168}$

In conclusion, given its open-ended nature as an effects-balancing test and its inherent unpredictability, the CHT cannot be the general test for analysing conduct under Article 102 . By the same token, the CHT has been reasonably criticised as being over-inclusive and overdeterrent. In cases where the standard of proof of consumer harm is high and its application becomes exacting, the test tends to produce false acquittals and under-deterrence. ${ }^{169}$ Moreover, if its scope is limited to short-run consumer effects, it may ultimately harm, rather than benefit, consumers. ${ }^{170}$ All things considered, the CHT cannot be the single test for finding an infringement of Article 102. It should be complemented by the other legal tests and supported by the residual values of EUCL. Integrated in such a framework, the CHT may offer optimal results.

\section{The Element of Intent}

The Test of Intent (ToI) introduces a form of categorical thinking onto the application of Article 102. More importantly, the ToI recognises the limits of a purely consequentialist approach and attempts to complement any assessment of the effects of a conduct. ${ }^{171}$ The ToI asks whether the behaviour in question is irrational "but for" its capability of eliminating or lessening competition". ${ }^{172}$ Additionally, when evidence of economic effects is dubious, the element of intent clarifies whether the conduct has an anti-competitive purpose or is aligned with competition on its merits.

The first objection to the ToI is that an anti-competitive intent can be readily confused with the intent to succeed in the market. ${ }^{173}$ This raises the risk of false positives. ${ }^{174}$ Such a

\footnotetext{
${ }^{167}$ Cases C-241/91 P and 242/91 P Radio Telefis Eireann (RTE) and Independent Television Publications Ltd (ITP) $v$ Commission of the European Communities [1995] ECR I-00743, para 54; Case T-504/93 Tiercé Ladbroke SA v Commission [1997] ECR II-923, para 131; Case C-418/01 IMS Health GmbH \& Co. OHG v NDC Health GmbH \& Co. KG. [2004] ECR I-05039, para 37.

168 Nazzini (n 15) 100-103.

169 ibid 94-95.

${ }^{170}$ David Evans and Atilano Padilla, 'Excessive Prices: Using Economics to Define Administrable Legal Rules' (2005) 1 (97) JCLE 114-116.

${ }^{171}$ Okeoghene Odudu, 'The Role of Specific Intent in Section 1 of the Sherman Act' (2002) 25 World Competition 463, 486-491; Lao (n 135) 192-199.

${ }^{172}$ Werden (n 133) 413.

${ }^{173}$ Herbert Hovenkamp, 'The Monopolization Offense' (2000) 61 OSLJ 1035, 1039; Frank Easterbrook, 'When Is It Worthwhile to Use Courts to Search for Exclusionary Conduct?' (2003) CBLR 345.

${ }^{174}$ Frank Easterbrook 'The Limits of Antitrust' (1984) 63 TLR 1.
} 
criticism is based on the fact that competitive and exclusionary behaviour may seem similar. ${ }^{175}$ In that respect, it presupposes that intent is a subjective element of the conduct itself. Nevertheless, if that were the case the ToI would be incompatible with EUCL since, pursuant to well-established CJEU jurisprudence, abuse is an "objective concept". 176 Furthermore, should a court find an infringement of Article 102 solely based on the state of mind of the perpetrator, that would trespass our legal intuitions, according to which no one should be punished for their evil intention. ${ }^{177}$ Hence, intent should be judged only after the aim, the context, the means, and the effects of the conduct in question have been thoroughly assessed. In order to be relevant, evidence of intent must relate to the intention to engage in conduct that does not fall within the scope of competition on the merits. ${ }^{178}$

For that purpose, ToI is established through a profit sacrifice test, which indicates whether or not a dominant undertaking's conduct makes economic sense. ${ }^{179}$ The profit sacrifice test appraises a dominant firm's behaviour as abusive if it sacrifices profits or incurs losses to an extent that would not make economic sense but for eliminating or excluding its rivals from the relevant market. ${ }^{180}$ This test is used especially for identifying predatory pricing as long as "predation in any meaningful sense cannot exist, unless there is a temporary sacrifice of net revenues in the expectation of greater future gains". ${ }^{181}$ This test was adopted by the Court in $A K Z O$ where it was held that pricing above AVC but below ATC is to be considered abusive "only if prices at that level are determined as part of a plan for eliminating a competitor". 182

Furthermore, the ToI may assist in reducing false convictions when objective data have proved inadequate for the finding of an infringement and an additional element is necessary to affirm anti-competitiveness. In other words, the ToI attempts to grasp the incentives and purposes of the dominant firm and examine the relation between them and the means engaged in their realisation. ${ }^{183}$ As an example, evidence of a deliberate plan to eliminate an efficient competitor can play a role in cases where a cost test is insufficient to

\footnotetext{
175 Posner (n 9) 214-215.

${ }^{176}$ Case C-85/76 Hoffman La Roche v Commission [1979] ECR I-461 para 91.

177 John Mill, On Liberty (first published 1859, Penguin Books 1986) 75-119.

178 Nazzini (n 15) 200-211.

${ }^{179}$ Joseph F Brodley, Patrick Bolton, Michael H Riordan, 'Predatory pricing: strategic theory and legal policy' (2000) 88 (8) GLJ 2239-330.

${ }^{180}$ Melamed (n 133) 1247, 1255.

${ }^{181}$ Phillip Areeda and Don Turner, 'Predatory Pricing and Related Practices under Section 2 of the Sherman Act' (1975) 88 (4) HLR 697.

${ }^{182}$ Case C-62/86 AKZO Chemie v Commission [1991] ECR I-03359, para 72; Guidance (n 97) paras 59, 60-63.

${ }^{183}$ Lao (n 135) 200-201.
} 
establish a prima facie predation. ${ }^{184}$ Thus, in fact, intent as a supplementary element of an anti-competitive practice guards against the risk of false convictions and over-deterrence. ${ }^{185}$

Another objection against the ToI is that it allows for false negatives. However, this argument cannot be accepted since intent is an objective notion relying on facts used to complement other empirical tests. This may be elucidated if we examine the practice of tying. Due to the severe uncertainty of counterfactual type tests in cases of tying, the CHT should be considered an inadequate test. Particularly, it is very difficult to prove that tying raises prices or restricts output. ${ }^{186}$ The investigation with regard to the foreclosure effect conducted by the Court has been insufficient. An additional element was required to reason its findings. ${ }^{187}$ In Tetra Pak II, for instance, the Court held that the relevant firm intended to make the tying product wholly dependent on the tied, which thereby amounted to a foreclosure effect. ${ }^{188}$ Undoubtedly, intent plays a key role in determining whether a tying practice is anti-competitive, since it allows the Court to take into account the overall strategy of the dominant firm. It is also induced so as to establish a capability of market foreclosure. ${ }^{189}$ Likewise, many scholars argue that a recoupment requirement should be a necessary element of the test, thus minimising the risk of false convictions. ${ }^{190}$

Following that, proof of intent may complement the shortcomings of other tests. As demonstrated above, the AECT may diminish effective competitive constraints and deprive a less efficient competitor of the opportunity to become an equally efficient one. In such a situation, evidence of a deliberate plan to exclude a competitor would in itself indicate that this competitor operates as an effective constraint on the dominant undertaking.

Be that as it may, it can still be argued that unintended practices that have a harmful effect on competition can be economically explained. As a result, these practices will not be prohibited under such a standard. ${ }^{191}$ Moreover, the profit sacrifice test may not be suitable in cases where the conduct in question is commercially rational, yet it has certain exclusionary

\footnotetext{
${ }^{184}$ Guidance (n 97) para 63.

185 Thomas Eilmansberger, 'How to distinguish good from bad competition under Article 82 EC: in search of clearer and more coherent standards for anti-competitive abuses' (2005) 42 CMLR 129, 148.

${ }^{186}$ For the belligerent debate on the subject see Bork (n 9) 372-373 and contrastingly, MD Whinston, 'Tying, Foreclosure, and Exclusion' (1990) 80 AER 837.

${ }^{187}$ Microsoft Corp. v Commission (n 94), paras 1031-1058.

${ }^{188}$ Case T-83/91 Tetra Pak International SA v Commission of the European Communities [1994] ECR II-00755, paras 134-135.

${ }^{189}$ Lao (n 135) 192-199.

${ }^{190}$ EP Mastromanolis, 'Predatory Pricing Strategies in the European Union: A Case for Legal Reform' (1998) 19 ECLR 211, 219-223; Brodley, Bolton, Riordan (n 179) 2267-2270.

${ }_{191}$ Amelia Fletcher, 'The reform of Article 82: recommendations on key policy objectives' (Competition Law Forum in Brussels, 15 March 2005) <http://www.oft.gov.uk/shared_oft/speeches/spe0205.pdf> accessed 25 August 2013; Elhauge (n 16) 253.
} 
effects, making some rather no economic sense. ${ }^{192}$ Similarly, not all types of abuse involve a profit sacrifice. For instance, raising a rival's costs could not be prohibited under a profitsacrifice test. ${ }^{193}$

These criticisms have merit and should be used to recognise the limits of the ToI. Therefore, intent cannot be an indispensable prerequisite for finding an abuse. It should always be supported by a substantive test of exclusionary conduct. ${ }^{194}$ It can be used as an analytical tool, contributing to the avoidance of false positives and false negatives. It covers some of the deficiencies of the other tests. ${ }^{195}$ Moreover, intent could reasonably bridge the gap between detrimental effects and theories of consumer harm. ${ }^{196}$ In addition, the element of intent should be taken into account to determine the gravity of the infringement when setting fines. ${ }^{197}$ Given that, intent can play a key role in the application of Article 102.

\section{E. CONCLUSION}

Positive law does not provide a strict framework of the objectives of EUCL, thus creating a normative conundrum. Choosing and balancing among protection of freedom to compete, preservation of an open and fair market, promoting innovation, industrial growth, welfare maximisation, consumers' protection and single market integration have caused a permanent concern for the CJEU. In a series of hard cases where the Court had to choose among conflicting goals, its findings have been unsatisfactory, or at least not widely accepted, thus undermining its legitimacy. Normative theories have striven for a long time to resolve this conundrum and subsequently facilitate the resolution of this adjudication problem.

The aim of this study was to assess whether the prevailing normative theories can in fact resolve the adjudication problem. It started with a critical evaluation of the two main normative approaches in EUCL. The various theories were categorised into two main approaches: the consequentialist and the deontological. The first argues that efficiency should be the ultimate objective of EUCL and thus CompL should be operationalised as an instrument for maximising welfare. The second doctrine focuses on the, inherent to competition, value of freedom. This argues that CompL should opt to realise a political or moral conception of freedom. Both approaches intend to unravel the abovementioned

\footnotetext{
192 Niels, Jenkins, Kavanagh (n 93) 185.

193 Steven Salop and David Scheffman, 'Cost-Raising Strategies' (1983) 73 (2) TAER 261-271.

194 Vickers (n 109) 250.

195 Nazzini (n 15) 219-221.

196 Bavasso (n 18) 620-621.

197 ibid 623.
} 
normative conundrum by providing an exegesis of what competition is and subsequently what objectives CompL should pursue. However, their endeavour to reduce EUCL to a single value or goal makes them susceptible to substantial criticism. On the contrary, value pluralism negates the idea that there can be strict causational links of subordination between the objectives of EUCL. As a result, the EUCL should promote a multitude of supplementary goals.

The second substantive part examined whether the two main approaches can identify the underpinning rationale of Article 102 and explain CJEU jurisprudence. The purpose of this investigation was to assess whether the current normative approaches can elucidate Article 102 and guide its interpretation. That being the case, these approaches would be able to resolve the adjudication problem concerning Article 102. Nonetheless, positive law and its application by the Court support the view that EUCL pursues a plethora of goals. A pluralistic perspective is further endorsed by the conclusion that the Court invokes deontological as well as consequentialist reasoning to deal with the disputes brought before it. The third part focused on the three tests applied for finding an infringement of Article 102. Given that no single test is suitable for application to all conceivable abusive practices, a test-plurality has been increasingly appealing. Concluding that the holistic approaches cannot provide complete guidance in the interpretation and application of Article 102, the paper suggests that a first step towards a value pluralistic perspective of EUCL should be made. Whether it can develop into a complete normative and adjudicative theory is to be appraised in the future. 